\title{
Community's social capital in the management of Mutis Timau Protected Forest in Timor Island, Indonesia
}

\author{
FRANSISKUS XAVERIUS DAKO^, RIS HADI PURWANTO, LIES RAHAYU W. FAIDA, SUMARDI \\ Faculty of Forestry, Universitas Gadjah Mada. J1. Agro No. 1, Bulaksumur, Sleman 55281, Yogyakarta, Indonesia. Tel./fax.: +62-274-512102. \\ vemail: dakoxaverjurnal@gmail.com.
}

Manuscript received: 10 May 2019. Revision accepted: 17 July 2019.

\begin{abstract}
Dako FX, Purwanto RH, Faida LRW, Sumardi. 2019. Community's social capital in the management of Mutis Timau Protected Forest in Timor Island, Indonesia. Biodiversitas 20: 2177-2187. The social capital of the community around Mutis Timau Protected Forest in Timor Island is unexplored. In fact, its social capital plays an important role to support sustainable management of the forest viewed from the ability of the community to work together in achieving common goals in groups and organizations. This study aimed to investigate the elements of community's social capital (i.e. norms, beliefs, and networks) in nine villages located in and around Mutis Timau Protected Forest administratively managed by the Forest Management Unit of South Central Timor District using quantitative survey approach. The result of the study showed that two villages have strong social capital while seven villages have moderate category. Overall, the communities have strong level on the elements of trust in individuals and others, and knowledge and understanding on unwritten rules, but have moderate level on the elements of written rules/regulations, trust in institutions and regulations, organizational network, and participation network. Community participation increases the understanding of written rules, institutional trust and improves the development of social networks (organizational networks and participation) between groups. This results can be used as a reference for the Forest Management Unit of South Central Timor District when developing cooperation with communities that have traditional knowledge and local wisdom through norms, beliefs, and networks in managing and utilizing natural resources in Mutis Timau Protected Forest. Furthermore, the involvement of people with social capital in managing Mutis Timau Protected Forest can maintain forest sustainability and improve community welfare.
\end{abstract}

Keywords: Community, management, protected forest, social capital

\section{INTRODUCTION}

Forest management cannot be separated from human as a part of social-ecological system (Budiharta et al. 2016) Many researchers conducted various studies on forest protected (e.g. Purnomo 2003; Ginoga et al. 2005; Nandini 2013; Hidayat 2014; Kurniadi et al. 2017; Dako et al. 2018) and these studies showed that forest protected faces many problems due to the increasing social difficulty of people living around the forest which is usually due to population growth, deforestation and land degradation, and reduced public access to natural resources (Simon 2003). Traditionally, the needs of community around the forest are fulfilled through natural resource management based on traditional knowledge, local wisdom, and ecological beliefs (Berkes 2009).

Social capital in natural resource and forest management has been studied in recent years (Hujala and Tikkanen 2008; Schluter and Koch 2011; Guillen et al. 2015; Górriz-mifsud et al. 2016; Kenny 2017; Roslinda et al. 2017; Roslinda 2018; Yoder and Roy 2018). Muslimah et al. (2015) define social capital as energy which is able to move the collective action of the community repetitively to produce a pattern of joint institutional activities. Social capital can be identified when there is a relationship (Usman 2018). It is related to social ties and norms (Coleman 1988), inherent relations and social capital through social networks (Putnam 1993), and aspects of organization that can facilitate collective action (Kusumastuti 2015). The concept of social capital in the field of forest governance includes networks, norms, and values of local communities that determine cooperation and contribute to their development (Górriz-mifsud et al. 2016).

Forest Management Unit (FMU) or Kesatuan Pengelolaan Hutan (KPH) of South Central Timor District was formed based on Governor's Regulation of East Nusa Tenggara Province Number 90 of 2016 and in line with the Minister of Environment and Forestry Decree Number 357/MenLHK/Setjen/PLA.0/5/2016 with an extent of 95,728.20 ha. Within this area, the FMU is also responsible to manage Mutis Timau Protected Forest (MTPF) which is classified as watershed protection forest (hutan lindung). In managing the forest, the FMU conducts to be less impacts, for instance, less community participation in planning, evaluation, and monitoring; and focuses only on biophysical activities (e.g. rehabilitation on degraded forests).

In managing forest landscape, it is not only based on biophysical aspects but should also consider social, economic and cultural factors. The Dawan Tribe is one of the largest tribes on the western part of Timor Island who lives in and around the MTPF and works as dryland farmers in either lowlands or highlands. In daily life, the members of the tribe keep up the customary rules through a mutual cooperative culture, respecting for the rules (written 
and unwritten), as well as having trust in individuals, and institutions within and outside the group. The interesting side of the characteristic of Dawan tribe is cooperation custom in groups (mutual cooperation) on every work and is always practiced up to now, such as clearing fields, planting, harvesting, building houses, customary affairs, and other social works. This culture has the meaning that social relations in the Dawan tribe contain norms, beliefs, and networks on the base of togetherness.

Based on those characteristics, it is important to explore the social capital owned by the Dawan Tribe community in regard to their dependence, role and participation in managing MTPF. This study aimed to investigate the elements of community's social capital (i.e. norms, beliefs, and networks) in managing MTPF administratively managed by the FMU of South Central Timor District. The results of this study can contribute to formulate social capital of communities living nearby MTPF for the management of natural resources by the FMU of South Central Timor District.

\section{MATERIALS DAN METHODS}

\section{Study area}

The research was conducted from January to May 2018 in nine villages around the MTPF under the management of the FMU of South Central Timor District. The nine villages namely Nunbena, Noebesi, Leloboko, Ajaobaki, Tunua, Nuapin, Nenas, Kuanoel and Fatumnasi (Figure 1). The rationale for choosing this location is as follows: (i) MTPF area is the largest extent of mountain forest on the western part of Timor Island with high biodiversity of distinctive mountain vegetation and two large watersheds, namely Benain and Noelmina; (ii) The norms, beliefs, networks and the interaction of people living around MTPF; (iii) Communities use MTPF area to supply their daily needs, such as the need for firewood, non-timber forest products, stockbreeding, and forest land for agricultural purposes.

\section{Research methodology}

The research method used was a survey and quantitative analysis with data collected through interviews using structured questionnaires. The sampling was carried out using simple random technique, while the number of respondents was determined using the Sevilla et al. (1993) approach with the formula as follows:

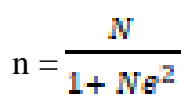

Where:

$\mathrm{n}=$ number of samples

$\mathrm{N}=$ population

$\mathrm{e}=$ tolerated error limit $(5 \%)$.

The number of respondents was 353 families of farmers of total 3004 families of all villages. The main concept of social capital in this study is the concept of social capital developed by Putnam et al. (1993). Putnam et al. (1993) argue that the concept of social capital refers to social organization features, such as norms, beliefs, and networks that can improve community efficiency by facilitating organization acts. Belief is the power to influence the principles of social welfare and economic progress achieved through community and social institution support (Putnam 1993). Norms are a set of rules that are expected to be obeyed by certain members of the entity. Norms cannot be separated from beliefs since norms are the devices used to keep consistency between status and role in maintaining social structures. While networks relate to typical typologies in line with the characteristics and orientation of the group (Putnam 1993). Social groups formed traditionally based on lineage equality beliefs (e.g. religious beliefs) tend to have high cohesion, but the reach of network or belief is skimpy. In contrast, groups built upon equality based on orientation and goals with more modern organizational management characteristics have a better level of member participation and a wider network reach (Roslinda 2018). The aspect of trust studied in this study consisted of individuals, family, and institutions. The norm and social network consist of written and unwritten rules, organizational and participation networks.

The social capital elements were assessed using a Likert scale with 3 categories: weak (value 1), moderate (value 2), and strong (value 3) for each question asked. The evaluation of social capital elements which resulted in maximal score (Xmax) when all questions have value of 3 and minimal score (Xmin) when all questions have value of 1 (Table 1).

Table 1. The evaluation of the social capital element

\begin{tabular}{|c|c|c|c|c|c|c|c|}
\hline \multirow{2}{*}{ Element of social capital } & \multirow{2}{*}{$\begin{array}{c}\text { Total } \\
\text { question }\end{array}$} & \multirow{2}{*}{$\mathbf{X m i n}$} & \multirow{2}{*}{ Xmax } & \multirow{2}{*}{$\mathbf{N}$} & \multicolumn{3}{|c|}{ Catagori score } \\
\hline & & & & & Weak & Moderate & Strong \\
\hline Written rules & 8 & 8 & 24 & 5.33 & $8-13.33$ & $13.33-18.66$ & $>18.66$ \\
\hline Unwritten rules & 10 & 10 & 30 & 6.6 & $10-16.66$ & $16.67-23.33$ & $>23.33$ \\
\hline Trust in individuals and others & 12 & 12 & 36 & 8 & $12-20$ & $20-28$ & $>28$ \\
\hline Trust in institutions and regulations & 9 & 9 & 27 & 6 & $9-15$ & $15-21$ & $>21$ \\
\hline Organizational network & 18 & 18 & 54 & 12 & $18-30$ & $30-42$ & $>42$ \\
\hline Participation network & 17 & 17 & 51 & 11.33 & $17-28.33$ & $28.33-39.66$ & $>39.66$ \\
\hline
\end{tabular}




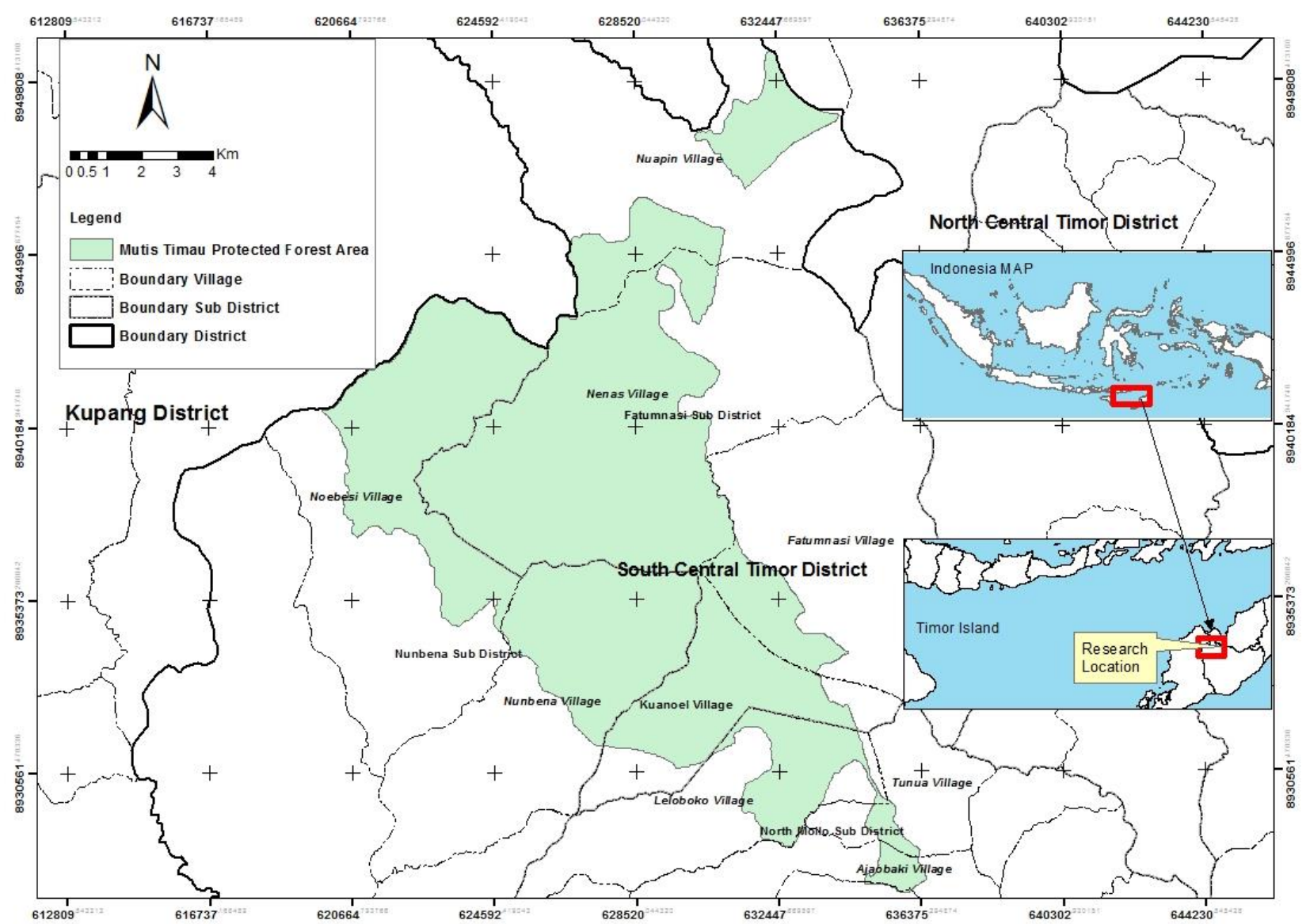

Figure 1. Map of the research location of Mutis Timau Protected Forest in the FMU of South Central Timor District, Timor Island, Indonesia

\section{RESULT AND DISCUSSION}

\section{Respondent characteristics}

Respondents of this study were families living in and around the MTPF and working as farmers (100\%) with male proportion of $89 \%$ and female of $11 \%$. Based on the level of education, $73.9 \%$ of respondents did primary school, $14.7 \%$ did junior high school and $11.3 \%$ did high school (Dako 2018). The very low level of education encouraged respondents to work in the agricultural sector as farmers, especially dryland farmers, and this largely influenced the level of knowledge and understanding of written and unwritten rules, beliefs, and networks. Nevertheless, the communities know and understand well the unwritten rules, such as customary rules.

The age of the respondents was dominated by $41-60$ years old with $54.4 \%$, while respondents with age of less than 40 years old were $34.3 \%$ and more than 60 years old was $11.3 \%$. The proportion of respondents having land area was $17 \%$ of respondents had land less than 0.5 ha, 76,5\% had $0.5-1$ ha and $6.5 \%$ had more than 1 ha. Because of population growth, there is a decrease in the land area per family. In term of the number of family members, $64.9 \%$ of respondents had 3-6 family members, $24.1 \%$ had less than 3 members and $11 \%$ had more than 6 members.
The respondents in the study area were indigenous people living there since they were born, although there were few outsiders come to the villages due to marriage. In term of staying in the village, $39.7 \%$ of respondents have been staying less than 25 years, $40.2 \%$ of respondents have been staying $25-47$ years, and $20.1 \%$ of respondents have been staying more than 47 years. It means that $60.3 \%$ of respondents know social-ecological systems of their villages, such as norms, beliefs, networks, and biophysical condition in their area.

The development of the community depends highly on empowerment programs from government and private sector to increase individual capabilities and groups, such as counseling and training activities. The proportion of the respondents who have never participated in counseling activities was $67.4 \%, 1-3$ times per year was $23.5 \%$, and more than 3 times per year was $9.1 \%$. This means that most respondents have never participated in counseling activities administered by government and private sector.

\section{Norms}

Social values and norms are used as references to achieve common goals, both at the group and community levels. Those who obey will be rewarded, while violators will be punished (Usman 2018). This is in line with the 
explanation of Hasbullah (2006) which states that norms are a set of rules that are expected to be obeyed and followed by community members. This contains social sanctions and determines behavior patterns in relationship context and plays a role in controlling people's behavior. The results of the study showed that social sanctions are strictly enforced in community's lives, such as communal land conflicts. Those who did wrong doing are given traditional fines, mainly a pig, $50 \mathrm{~kg}$ of rice, and betel place containing one piece of silver money. The fines given are then cooked and eaten with all communities and witnessed by the government to make a report on traditional peace signed by both parties. Also, other social problems and social sanctions are always given by traditional leaders based on the level of problems carried out and obediently accepted by the community.

Table 2. The results of assessment on the element of social capital of written rules

\begin{tabular}{|c|c|c|c|c|c|c|c|c|c|c|}
\hline \multirow{2}{*}{ Indicator of written rules } & \multicolumn{9}{|c|}{ Village } & \multirow{2}{*}{$\begin{array}{l}\text { Average } \\
\text { of score }\end{array}$} \\
\hline & Nunbena & Noebesi & Leloboko & Tunua & Ajaobaki & Nuapin & Nenas & Kuanoel & Fatumnasi & \\
\hline Compliance and obedience to religious values & 2.53 & 2.42 & 2.34 & 2.5 & 2.35 & 2.35 & 2.48 & 2.35 & 2.44 & 2.41 \\
\hline Knowledge on the rules about community's life & 2.57 & 2.45 & 2.34 & 2.5 & 2.39 & 2.5 & 2.38 & 2.45 & 2.58 & 2.46 \\
\hline $\begin{array}{l}\text { Knowledge of government regulations regarding } \\
\text { protected forest management }\end{array}$ & 1.42 & 1.68 & 1.52 & 1.34 & 1.5 & 1.56 & 1.64 & 1.56 & 1.64 & 1.54 \\
\hline $\begin{array}{l}\text { Compliance and adherence to written rules in protected } \\
\text { forest management agreements between communities } \\
\text { and the government }\end{array}$ & 1.61 & 1.65 & 1.65 & 1.56 & 1.56 & 1.6 & 1.61 & 1.56 & 1.62 & 1.6 \\
\hline $\begin{array}{l}\text { Understanding of government regulations regarding } \\
\text { protected forest management }\end{array}$ & 1.57 & 1.6 & 1.69 & 1.5 & 1.54 & 1.5 & 1.67 & 1.62 & 1.58 & 1.58 \\
\hline Understanding the rules about community's life. & 2.34 & 2.48 & 2.43 & 2.76 & 2.39 & 2.54 & 2.67 & 2.48 & 2.58 & 2.51 \\
\hline The level of public violation on written rules & 2.07 & 2 & 1.78 & 2.06 & 2.06 & 1.96 & 1.87 & 2.02 & 1.88 & 1.96 \\
\hline Sanctions for violations committed & 2 & 1.97 & 1.95 & 1.98 & 1.97 & 1.9 & 2.03 & 1.96 & 2.16 & 1.99 \\
\hline Total & 16.11 & 16.25 & 15.7 & 16.2 & 15.76 & 15.91 & 16.35 & 16 & 16.48 & 16.05 \\
\hline
\end{tabular}

Table 3. The results of assessment on the element of social capital of unwritten rules

\begin{tabular}{|c|c|c|c|c|c|c|c|c|c|c|}
\hline \multirow{2}{*}{ Indicator of unwritten rules } & \multicolumn{9}{|c|}{ Village } & \multirow{2}{*}{$\begin{array}{l}\text { Average } \\
\text { of score }\end{array}$} \\
\hline & Nunbena & Noebesi & Leloboko & Tunua & Ajaobaki & Nuapin & Nenas & Kuanoel & Fatumnasi & \\
\hline Knowledge of norms and customs in society & 2.42 & 2.57 & 2.39 & 2.48 & 2.47 & 2.43 & 2.58 & 2.54 & 2.4 & 2.48 \\
\hline Understanding of norms and customs in society & 2.42 & 2.4 & 2.39 & 2.38 & 2.45 & 2.41 & 2.54 & 2.67 & 2.38 & 2.45 \\
\hline $\begin{array}{l}\text { Compliance and adherence to unwritten rules in forest } \\
\text { management }\end{array}$ & 2.34 & 2.4 & 2.39 & 2.46 & 2.41 & 2.39 & 2.51 & 2.45 & 2.44 & 2.42 \\
\hline The level of violation of unwritten rules is very low & 2.38 & 2.34 & 2.26 & 2.36 & 2.37 & 2.32 & 2.38 & 2.37 & 2.36 & 2.35 \\
\hline Relatively light violation sanctions & 2.34 & 2.31 & 2.21 & 2.34 & 2.35 & 2.3 & 2.35 & 2.35 & 2.34 & 2.32 \\
\hline Rituals for land clearing and harvest thanksgiving & 2.38 & 2.37 & 2.43 & 2.44 & 2.45 & 2.47 & 2.45 & 2.35 & 2.38 & 2.41 \\
\hline $\begin{array}{l}\text { Distribution of yields to the needy or the church as an } \\
\text { expression of gratitude }\end{array}$ & 2.5 & 2.4 & 2.47 & 2.44 & 2.45 & 2.43 & 2.41 & 2.37 & 2.4 & 2.43 \\
\hline Prioritizing politeness norms in community life & 2.34 & 2.42 & 2.34 & 2.5 & 2.39 & 2.43 & 2.45 & 2.45 & 2.44 & 2.42 \\
\hline Prioritizing harmony in community life & 2.38 & 2.42 & 2.43 & 2.4 & 2.47 & 2.41 & 2.51 & 2.43 & 2.42 & 2.43 \\
\hline Promote honesty in community life & 2.34 & 2.45 & 2.34 & 2.42 & 2.45 & 2.41 & 2.35 & 2.4 & 2.46 & 2.40 \\
\hline Total & 23.84 & 24.08 & 23.65 & 24.22 & 24.26 & 24 & 24.53 & 24.38 & 24.02 & 24.11 \\
\hline
\end{tabular}

Table 4. The results of assessment on the element of social capital of trust in individuals and others

\begin{tabular}{|c|c|c|c|c|c|c|c|c|c|c|}
\hline \multirow{2}{*}{ Indicator of trust } & \multicolumn{9}{|c|}{ Village } & \multirow{2}{*}{$\begin{array}{l}\text { Average } \\
\text { of score }\end{array}$} \\
\hline & Nunbena & Noebesi & Leloboko & Tunua & Ajaobaki & Nuapin & Nenas & Kuanoel & Fatumnasi & \\
\hline $\begin{array}{l}\text { Trust between people (neighbors, friends, family, } \\
\text { groups) }\end{array}$ & 2.38 & 2.4 & 2.43 & 2.52 & 2.56 & 2.56 & 2.48 & 2.59 & 2.64 & 2.51 \\
\hline Trust between individuals from the same tribe & 2.5 & 2.42 & 2.47 & 2.54 & 2.6 & 2.5 & 2.51 & 2.48 & 2.5 & 2.50 \\
\hline Trust in individuals from other tribes & 2.26 & 2.34 & 2.13 & 2.38 & 2.37 & 2.07 & 2.35 & 2.35 & 2.36 & 2.29 \\
\hline Trust in religious leaders & 2.38 & 2.42 & 2.34 & 2.44 & 2.54 & 2.49 & 2.38 & 2.56 & 2.38 & 2.44 \\
\hline Trust in police officers & 2.5 & 2.37 & 2.34 & 2.58 & 2.5 & 2.52 & 2.54 & 2.59 & 2.54 & 2.50 \\
\hline Trust in community leaders & 2.42 & 2.4 & 2.39 & 2.4 & 2.47 & 2.54 & 2.58 & 2.62 & 2.62 & 2.49 \\
\hline Trust in the group leader & 2.34 & 2.48 & 2.43 & 2.56 & 2.52 & 2.52 & 2.48 & 2.56 & 2.52 & 2.49 \\
\hline Trust in FMU officers & 2.38 & 2.37 & 2.39 & 2.54 & 2.43 & 2.58 & 2.54 & 2.43 & 2.6 & 2.47 \\
\hline Trust in officers from other agencies & 2.5 & 2.45 & 2.39 & 2.46 & 2.54 & 2.54 & 2.58 & 2.56 & 2.54 & 2.51 \\
\hline Trust in forestry police & 2.38 & 2.45 & 2.43 & 2.56 & 2.58 & 2.49 & 2.54 & 2.45 & 2.52 & 2.49 \\
\hline Trust in borrowing from one another & 2.46 & 2.4 & 2.39 & 2.48 & 2.5 & 2.64 & 2.64 & 2.4 & 2.56 & 2.50 \\
\hline Trust in village officials & 2.53 & 2.37 & 2.52 & 2.44 & 2.52 & 2.56 & 2.67 & 2.51 & 2.54 & 2.52 \\
\hline Total & 29.03 & 28.87 & 28.65 & 29.9 & 30.13 & 30.01 & 30.29 & 30.1 & 30.32 & 29.71 \\
\hline
\end{tabular}


Table 2 above shows that community's knowledge and understanding about written norms/rules in the nine villages are in moderate category with average score of 16.05 with the highest is in Fatumnasi Village (16.48) and the lowest is in Leloboko (15.7). The communities around the MTPF are very obedient to religious and noble cultural values. As the area is dominated by Protestant Christians, intrinsic values through faith and trust are always conveyed with love and inherent in social and cultural norms, while cultural values consist of entity's knowledge and understanding. People know and understand social norms such as religious, decency, law, politeness, and habits. It can be understood that written regulations implemented daily by the community are intended to organize their life. Regulations have a positive impact on adjusting social lives that must be respected. Those who break the regulations will be given social sanctions in the form of customary fines. In line with this, Senoadji (2011) explained that customary norms and rules govern all things in life such as land, community life, forest resources, and the environment.

However, the most prevalent problem is the low knowledge and understanding of community on written government regulations due to the lack of socialization conducted by either the FMU or local government of South Central Timor District which is in line with Roslinda et al. (2017). The level of violations and sanctions is in the moderate category. Rijal and Noer (2013) stated that sanctions that are fair and applied to every actor without exception provides a deterrent effect for the perpetrators and their families.

The results show that the community's knowledge and understanding on unwritten regulations and norms/rules in the nine villages around the MTPF is in strong category with an average score of 24.11 with Nenas Village being the highest (24.53) and Leloboko being the lowest with 23.65 (Table 3 ). The high level of community's knowledge and understanding on unwritten regulations is due to the fact that the traditional leaders continuously promote and provide strict sanctions in the form of customary fines for those who break these unwritten regulations. Social sanctions given to the community are similar to every village because they share the same tribe namely Dawan Tribe. Maladi (2010) states that norms or customary laws are used to solve various legal problems faced by society daily. In utilizing forest products from the forest, the communities inside and around the MTPF always follow the norms, cultures, and traditions in the community. Unwritten rules in the community include rules/order in people's lives, rules for taking firewood, taking honey bees, grazing livestock, taking non-timber forest products, clearing agricultural land, planting agricultural crops and harvesting agricultural products.

According to Parlinah et al. (2018), unwritten laws are more effectively applied in terms of forest reservation and preservation. Roslinda et al. (2017), stated that community understands the written rules as part of its forest management. An interesting point in managing agricultural land in the study areas is the use of slash-and-burn method. Before cultivating the land, the community appealed to the atoin meto who had the divine power that governs their lives namely uis neno (Lord of the heavens) and uis pah (Lord of the earth). Any activities, both personal and collective, especially in agricultural activities, always begs the atoin meto (Matheos Anin, pers. comm). Every individual in the community always recites a prayer of thanksgiving to the atoin meto for harvested results and manifested through the offerings of the best agricultural products that were delivered at the Sunday service.

The harmony between individuals makes it easier for them to carry out various activities. Conflict resolution can be done using customary rules because most community members are honest (Liu et al. 2014). The Dawan Tribe community always puts forward an attitude of love, courtesy, cooperation, and honesty, as they believe these brings blessings and fortune.

\section{Trust}

In term of level of trust individually and collectively, in average the nine villages around the MTPF have strong level of trust with score of 29.71 with Fatumnasi Village being the highest (30.32) and Leloboko being the lowest (28.65) (Table 4). These results indicate that the communities have a culture of mutual trust inherited from their ancestors and are always embedded in everyone. They believe that mutual trust can facilitate their future lives. Originating from the similar tribe (i.e. Dawan Tribe) and having a kinship relationship encouraged their awareness to trust each other in doing all activities (take and give) within the family and the group. People always teach honesty, openness, politeness, and mutual trust. The Dawan Tribe community accepts differences with the spirit of love in courtesy, honesty, and openness which implies trust in religious and community leaders, village officials, police, and FMU officers, livestock officers, agriculture officers, environment officers, tourism officers, and nongovernmental organizations. The village development programs have been focused on education, economics, and health. To achieve success, the village government encouraged its citizens to form farmer groups with its members trusting their leader that the leader would help them in achieving prosperity.

The high level of trust is due to religious values which comprise of politeness, harmony, and honesty. It is also based on mutual trust and cooperation in the community (Parlinah et al. 2018) which makes it easier for members to mobilize resources and also make institutional modifications as an effort to redefine the rules (Kusumastuti 2015). Interaction is repeatedly conducted to determine various problems and provide adequate time to help build personal and organizational trust (Schluter and Koch 2011). An officer who has worked in the area for a long time creates personal relationships with the residents (Hujala and Tikkanen 2008). Trust requires local personnel with contextual knowledge about the forest and its owners. However, this tends to change with change in staff (Guillén et al. 2015). Excessive dependence on personal attachments can also be negative, therefore more social capital is required.

Table 5 shows that the level of trust in institutions and regulations in six villages is in moderate category with a 
total score of 20.51 to 21 while the rest of three villages is in strong category with the score of 21.06 to 21.44 . The highest level of trust in institution and regulation is in Nenas Village with the score of 21.44 and the lowest level is in Nunbena with the score of 20.51, and overall the level of trust in the nine villages are in moderate category with average score of 20.96 .

The presence of public trust in institution and regulation is caused by the presence of government and private institutions with their regulations that have a cooperative relationship with the community by doing empowerment activities and have access to the institutions. Although communities believe in written regulations, but they have a very low level of acceptance and understanding due to the lack of socialization from the government. This is very different from unwritten regulations that have a very high level of acceptance and understanding because they are always socialized and carried out into their social life. A program/activity works well when it has clear objectives with clear planning, organization, supervision, and evaluation activities. Institutions such as central and regional governments, Non-governmental Organizations (NGOs) and farmer groups conduct various formal/informal development programs/activities. The communities in and around the MTPF have a high level of trust in the institutions of the regional governments (village, sub-district, and South Central Timor district), the FMU of South Central Timor, East Nusa Tenggara Province Forest Service, the Natural Resources Conservation Center of East Nusa Tenggara (Balai Konservasi Sumber Daya Alam/BKSDA), and NGOs such as WWF Nusa Tenggara, Samantha and other local NGOs. Despite the level of public trust in both written and unwritten regulations is very high, their acceptance in accordance to written regulations is very low. According to Roslinda et al. (2017), community does not believe in the effectiveness of written regulations with respect to forest conservation since it has not been internalized as values that need to be recognized, respected and have not been proven effective for managing and conserving forests, while unwritten rules are hereditary and internalized in society.

Table 5. The results of assessment on the element of social capital of trust in institutions and regulations

\begin{tabular}{|c|c|c|c|c|c|c|c|c|c|c|}
\hline \multirow{2}{*}{ Indicator of trust } & \multicolumn{9}{|c|}{ Village } & \multirow{2}{*}{$\begin{array}{l}\text { Average } \\
\text { of score }\end{array}$} \\
\hline & Nunbena & Noebesi & Leloboko & Tunua & Ajaobaki & Nuapin & Nenas & Kuanoel & Fatumnasi & \\
\hline Trust in the FMU of South Central Timor District & 2.38 & 2.4 & 2.65 & 2.64 & 2.6 & 2.56 & 2.58 & 2.51 & 2.44 & 2.53 \\
\hline Trust in NGOs & 2.46 & 2.42 & 2.39 & 2.42 & 2.62 & 2.52 & 2.64 & 2.72 & 2.78 & 2.55 \\
\hline Trust in written rules & 2.23 & 2.22 & 2.08 & 2.34 & 2.41 & 2.33 & 2.61 & 2.37 & 2.38 & 2.33 \\
\hline Level of acceptance on written regulations & 1.15 & 1.62 & 1.47 & 1.44 & 1.2 & 1.26 & 1.38 & 1.43 & 1.2 & 1.35 \\
\hline Trust in unwritten rules & 2.46 & 2.6 & 2.52 & 2.46 & 2.47 & 2.39 & 2.45 & 2.48 & 2.46 & 2.48 \\
\hline The level of acceptance on unwritten regulations & 2.34 & 2.4 & 2.39 & 2.36 & 2.39 & 2.35 & 2.35 & 2.37 & 2.42 & 2.37 \\
\hline Trust in the East Nusa Tenggara Provincial Forestry Service & 2.5 & 2.34 & 2.47 & 2.42 & 2.39 & 2.35 & 2.38 & 2.35 & 2.36 & 2.40 \\
\hline Trust in the Natural Resources Conservation Center of NTT & 2.53 & 2.37 & 2.39 & 2.46 & 2.45 & 2.54 & 2.51 & 2.62 & 2.5 & 2.49 \\
\hline Trust in the South Central Timor District regional government & 2.46 & 2.37 & 2.43 & 2.4 & 2.47 & 2.41 & 2.54 & 2.56 & 2.52 & 2.46 \\
\hline Total & 20.51 & 20.74 & 20.79 & 20.94 & 21 & 20.71 & 21.44 & 21.41 & 21.06 & 20.96 \\
\hline
\end{tabular}

Table 6. The results of assessment on the element of social capital of organizational network

\begin{tabular}{|c|c|c|c|c|c|c|c|c|c|c|}
\hline \multirow{2}{*}{ Indicator of organizational network } & \multicolumn{9}{|c|}{ Village } & \multirow{2}{*}{$\begin{array}{l}\text { Average } \\
\text { of score }\end{array}$} \\
\hline & Nunbena & Noebesi & Leloboko & Tunua & Ajaobaki & Nuapin & Nenas & Kuanoel & Fatumnasi & \\
\hline Existence of an organization & 2.38 & 2.48 & 2.34 & 2.56 & 2.52 & 2.52 & 2.64 & 2.54 & 2.56 & 2.50 \\
\hline Organizational membership & 2.5 & 2.45 & 2.52 & 2.6 & 2.43 & 2.43 & 2.45 & 2.56 & 2.5 & 2.49 \\
\hline Get engage each other among members in the organization & 2.42 & 2.42 & 2.56 & 2.52 & 2.45 & 2.52 & 2.51 & 2.59 & 2.44 & 2.49 \\
\hline Organizations are formed at the initiative of the community & 2.65 & 2.37 & 2.43 & 2.48 & 2.58 & 2.37 & 2.58 & 2.51 & 2.52 & 2.50 \\
\hline Deliberation and consensus in the election of group leaders & 2.53 & 2.4 & 2.47 & 2.46 & 2.58 & 2.49 & 2.41 & 2.45 & 2.34 & 2.46 \\
\hline Decision making is done by the group leader & 2.46 & 2.34 & 2.56 & 2.4 & 2.56 & 2.39 & 2.48 & 2.43 & 2.56 & 2.46 \\
\hline Groups provide benefits for members & 2.57 & 2.48 & 2.65 & 2.38 & 2.58 & 2.41 & 2.51 & 2.48 & 2.48 & 2.50 \\
\hline Organization is structurized according to needs & 2.53 & 2.37 & 2.34 & 2.42 & 2.47 & 2.35 & 2.48 & 2.45 & 2.42 & 2.43 \\
\hline Involvement in the organization & 2.42 & 2.34 & 2.34 & 2.4 & 2.45 & 2.37 & 2.45 & 2.27 & 2.44 & 2.39 \\
\hline Determinants of someone becoming a group member & 2.46 & 2.37 & 2.39 & 2.44 & 2.43 & 2.45 & 2.38 & 2.35 & 2.52 & 2.42 \\
\hline $\begin{array}{l}\text { The desire to share experiences and knowledge with } \\
\text { other members }\end{array}$ & 2.53 & 2.37 & 2.34 & 2.46 & 2.45 & 2.5 & 2.41 & 2.51 & 2.42 & 2.44 \\
\hline Ease to get information from other members & 2.46 & 2.4 & 2.43 & 2.44 & 2.43 & 2.35 & 2.45 & 2.45 & 2.48 & 2.43 \\
\hline Submission of information to other members & 1.76 & 1.57 & 1.47 & 1.72 & 1.85 & 2.01 & 1.83 & 2.02 & 1.98 & 1.80 \\
\hline $\begin{array}{l}\text { Frequency of interaction of farmer groups with outside } \\
\text { parties to obtain information }\end{array}$ & 1.34 & 1.4 & 1.47 & 1.66 & 1.7 & 1.5 & 1.54 & 1.24 & 1.62 & 1.50 \\
\hline Frequency of participation in organizations or groups & 1.11 & 1.54 & 1.39 & 1.78 & 1.29 & 1.41 & 1.41 & 1.29 & 1.54 & 1.42 \\
\hline Motivation to work with other parties & 2.53 & 2.42 & 2.34 & 2.36 & 2.41 & 2.47 & 2.61 & 2.48 & 2.46 & 2.45 \\
\hline Form and nature of community social networks & 2.46 & 2.34 & 2.39 & 2.44 & 2.39 & 2.43 & 2.48 & 2.54 & 2.44 & 2.43 \\
\hline Methods of developing organizational networks & 2.5 & 2.4 & 2.43 & 2.4 & 2.47 & 2.43 & 2.45 & 2.48 & 2.4 & 2.44 \\
\hline Total & 41.61 & 40.46 & 40.86 & 41.92 & 42.04 & 41.4 & 42.07 & 41.64 & 42.12 & 41.55 \\
\hline
\end{tabular}


Trust in institutions occurs because of the interaction between the FMU and the local community. However, building trust with local communities requires hard work. Value differences between owners and stakeholders or topdown reforms are obstacles to building trust (Nystenhaarala 2013). The relationship between public trust and the South Central Timor District is built upon the interests of the community in utilizing forest products with traditional knowledge and local wisdom values. The FMU of South Central Timor District is an institution that has the authority to manage forest and protect its resources which may cause the FMU prohibits people from accessing the MTPF area. According to Berlin and Lidestav (2006), interest incompatibility causes loss of trust. Its values are the basis of rural communities in increasing respect and mutual benefit (Cahyono and Adhitama 2012). Trust in institutions is constitutive and is a factor that determines potential function regions (Tulaeva 2013).

\section{Social network}

The community's network starts from the family based on similarity of entities which work together in agriculture, animal husbandry and other sectors. The concept of regional development enhances welfare and triggers the formation of groups whose members come from the same tribe and family. It has a strong attachment in agriculture, and politics. Farmer groups as organizations are controlled by rules with mutually agreed procedures. Decision making and responsibility are determined by referring to common interests. Some people may ignore their formal procedures and responsibilities and make a personal approach which seems to be an easier way to get something compared to following processes and rules. Social networks are valuable assets because everyone tends to get the same assistance without special relationship (Field 2003).

Table 6 shows the assessment on organizational networks in which three villages have strong level of networks with score of more than 42 (Ajaobaki $=42.04$, Nenas $=42.07$ and Fatumnasi $=42.12$ ), while six villages including Nunbena (score 41.61), Noebesi (score 40.46), Leloboko (score 40.86), Tunua (score 41.92), Nuapin (score 41.4), and Kuanoel (score 41.64) are in the moderate category (score 32-42) so that the overall category is moderate (score 41.55).

The network of organizations in the nine villages around the MTPF comprises of a farmer group who exchange information and interests. Farmers' networks in Ajaobaki, Nenas, and Fatumnasi villages are highly developed both in terms of quantity and quality compared to other six villages. Members have networks between individuals within and outside the groups to carry out various programs/activities delivered by the governments as well as non-governmental organizations to improve community welfare through various extension and empowerment activities. Most members of farmer groups in each village are from the Dawan tribe, thereby, creating an emotional bond. Family relationships enhance cooperation within farmer groups with each member involved in group activities and decision-making process in order to achieve a common goal.

The relationship of interaction between members inside and outside the farmer group is based on the ability to share information, experience, and knowledge with others. This is in line with Borg et al. (2015) opinion which stated that the exchange of information and bonds of trust are reciprocal. The form and nature of the organization's network in this study are informal (farmer groups) through family relationships and friendships. The form of community social networks with the FMU of South Central Timor District is vertical or symbiotic mutualism while the relationship between farmer groups is horizontal. The FMU always collaborates with farmer groups in forest rehabilitation and security activities, while the community cooperates to obtain NTFPs.

Basically, every leader develops networks and interactions outside the community, but collectively these are developed at the internal level (Kusumastuti 2015). Paletto et al. (2012) stated that network weakness is indicated by a decrease in the quality of relationships. When it is formed in society it tends to be informal. In addition, the group also has good relations with external parties such as Non-governmental Organizations (NGOs) that play a role in community development (Roslinda et al. 2017). Network structures form information flows, power relations, trust, and the spread of innovation (Gorriz-mifsud et al. 2017). In general, the Dawan Tribe community always invites surrounding farmers to participate in cultivating the land and other social activities.

Community participation in a network is manifested through social involvement in various activities of farmer groups. The results of the research indicate that the highest network participation is in Fatumnasi Village with the score of 39.14 and the lowest is in Leloboko Village with the score of 37.01 , and overall the nine villages are in moderate category with the score of 38.02 (Table 7). These quantitative values are in line with field observation at the study locations that community participation through farmer groups is more developed in Fatumnasi and Nenas villages compared to other villages. Farmer groups in Fatumnasi and Nenas Village are very active in various empowerment activities facilitated by either government or NGO, and supported by social participation in every activity of farmer groups. Table 7 describes the active participation of farmer group members in group activities such as meetings, counseling, planting, and cattle raising. However, group meetings are only carried out in accordance with the community which is not proportional and symmetrical when expressing opinions. Group members follow the opinions of those with higher education. Dissent will be resolved by deliberation and consensus. Communities and farmer groups always work together and participate in various activities both inside and outside the group. In increasing solidity, information and technology should be developed, and farmer groups should collaborate with other organizations within and outside the community. 
The Dawan community always lives in groups with great concern for each member and for the environment by planting crops in agroforestry patterns. This pattern comes from sincere intentions and ancestral heritage that is embedded in them. Conversely, there is low effort of empowerment carried out by individuals from inside and outside the group due to the lack of assistance by the government. Internal conflicts on social networks of participation are resolved by administrators and members, while external conflicts are resolved through deliberations and consensus with other groups.

People always depend on others through social networking relationships with environmental regulations higher than formal institutions (Bodin and Crona 2009). It also strengthens relationships between individuals and encourages them to cooperate. The network of participation is built because of the similarity of economic, educational, cultural and ethnic backgrounds with other members (Muslimah et al. 2015). This similarity facilitates the development of solidity and solidarity in collaborating especially in empowerment activities. Ramansyah et al. (2015) stated that the ability of group members to participate in social networks is one of the keys to successful development of social capital. The high participation in social networks can be seen from the existing support, such as volunteerism, equality, freedom, and openness. Parlinah et al. (2018) stated participation is not only realized in mutual cooperation activities in the construction of houses or public facilities (such as roads and irrigation channels), but also in the form of donations of materials such as wood to build places of worship places and schools.

When summing up of all elements of social capital in nine villages around MTPF, Nenas (173.8) and Fatumnasi (173.14) have strong community social capital (score> 172.66), while Nunbena (score 168.12), Noebesi (score 167.73), Leloboko (score 166.6), Tunua (score 171.18), Ajaobaki (score 171.84), Nuapin (score 169.46) and
Kuanoel (score 171.98) are at the moderate level (score 123-172.66). These results indicate that the elements of community social capital in the Dawan Tribe are inherent in their lives. To strengthen this, empowerment is needed to increase their knowledge and understanding of written rules, trust in institutions and regulations, and the development of social networks. However, knowledge and understanding of unwritten rules, as well as trust in individuals and others, have been very well understood by the community and are in a strong category.

At present, social capital owned by the community is a natural force that can be used in managing natural resources, especially in the MTPF and it can rapidly develop if it gets empowerment input. Social capital is an important element that makes it easy for the FMU of South Central Timor District to work with local communities using traditional knowledge and local wisdom through a normative, trustworthy and network approach to manage and utilize natural resources in the MTPF. The norms, beliefs, and networks found in the nine villages around the MTPF will be stronger if they have good teamwork, high commitment and mutual trust among social members. The group members should know and understand social norms and realities in social life. On the contrary, social capital will be weak if it does not have as it is found in strong social capital. Hasbullah (2006) stated the strength of social capital depends on the capacity of community groups to associate and build their networks. One of the keys to the successful development of social capital lies in the ability of individuals in organizations to participate in social networks. According to Uphoff (2000), people who have a high level of social capital have following aspect: (i) Commitment to joint efforts and cooperation occurs when this has a positive influence on many people, (ii) Social values that lead to effective cooperation, (iii) Collective action-oriented to the success of sustainable resource use, (iv) Institutionalized use of resources, and (v) Willingness to increase productivity.

Table 7. The results of assessment on the element of social capital of network participation

\begin{tabular}{lcccccccccc}
\hline \multirow{2}{*}{ Indicator of network participation } & \multicolumn{4}{c}{$\begin{array}{c}\text { Village } \\
\text { Average }\end{array}$} \\
\cline { 2 - 6 } of score
\end{tabular}


In conclusion, norms, beliefs, and networks are inherent in the Dawan Tribe communities around the MTPF in building relationships within and among groups. The Dawan Tribe community respects both written and unwritten norms with their respective levels of knowledge and understanding. However, the community trusts in individuals, institutions, and regulations. Overall, the level of community social capital in two villages (Nenas and Fatumnasi) is in a strong category, and moderate in seven villages (Nunbena, Noebesi, Leloboko, Tunua, Ajaobaki, Nuapin and Kuanoel). The FMU of South Central Timor District should strengthen social capital for villages through increasing knowledge and understanding of written rules, trust in institutions and regulations, and the development of networks through organizations and participation. Social capital is an important element that facilitates cooperation between the FMU of South Central Timor District and traditional-insight and local wisdom communities through normative approaches, trust, and networks in the management and utilization of natural resources at MTPF.

\section{ACKNOWLEDGEMENTS}

The researcher would like to thank the Ministry of Research, Technology and Higher Education for providing the opportunity to continue the BUDI-DN Doctoral Education Program and the Ministry of Finance for providing research funding and educational facilities during the study through the Education Fund Management Institution (LPDP). Special appreciation to the Head of FMU of South Central Timor District, the heads of the nine villages where the research was conducted, and to the community members (respondents) for their assistance.

\section{REFERENCES}

Berkes F. 2009. Evolution of co-management: role of knowledge generation, bridging organizations and social learning. J Env Man 90 (5): 1692-1702.

Berlin C, Lidestav G. 2006. Values placed on forest property benefits by Swedish NIPF owners: differences between members in forest owner associations. Small Scale For Econ Man Pol 5 (1): 83-96.

Bodin O, Crona BI. 2009. The role of social networks in natural resource governance: what relational patterns make a difference? J Glob Environ Cha 19: 366-374.

Borg R, Toikka A, Primmer E. 2015. Social capital and governance : a social network analysis of forest biodiversity collaboration in Central Finland. J For Pol Econ 50: 90-97.

Budiharta S, Meijaard E, Wells JA, Abram NK, Wilson K. 2016. Enhancing feasibility: incorporating a socio-ecological systems framework into restoration planning. J Environ Sci Policy 64: 83-92

Cahyono B, Adhitama A. 2012. Peran modal sosial dalam peningkatan kesejahteraan masyarakat petani tembakau. In: Proc Conf In Business Accounting Manag 1: 31-144. [Indonesian]

Coleman JS. 1988. Social capital in the creation of human capital. Am J Sociol 94 (3): 95-120.

Dako FX, Purwanto RH, Faida LRW, Sumardi. 2018. Firewood and carpentry wood contribution to the communities of Mutis Timau protected forest, Timor Island. Jurnal Manajemen Hutan Tropika 24 (3): 166-174. [Indonesia]

Field J. 2003. Social Capital. Routledge, London.
Ginoga K, Lugina M, Djaenudin D. 2005. Kajian kebijakan hutan lindung. Jurnal Penelitian Sosial dan Ekonomi 2 (2): 203-231. [Indonesian]

Gorriz-mifsud E, Secco L, Da R, Pisani E, Alcalde A, Roure R. 2017. Structural social capital and local-level forest governance: do they inter-relate? a mushroom permit case in Catalonia. J Env Man 188 (2017): 364-378.

Górriz-mifsud E, Secco L, Pisani E. 2016. Exploring the interlinkages between governance and social capital : a dynamic model for forestry. J For Pol Econ 65 (2016): 25-36.

Guillén LA, Wallin I, Brukas V. 2015. Social capital in small-scale forestry: a local case study in Southern Sweden. J For Pol Econ 53: 21-28.

Hasbullah J. 2006. Social capital (Menuju keunggulan budaya manusia Indonesia). Cetakan pertama. MR-United Press, Jakarta. [Indonesia]

Hidayat S. 2014. Kondisi vegetasi di hutan lindung Sesaot, Kabupaten Lombok Barat, Nusa Tenggara Barat sebagai informasi dasar pengelolaan kawasan. J Penelitian Kehutanan Wallacea 3 (2): 97-105. [Indonesia]

Hujala T, Tikkanen J. 2008. Boosters of and barriers to smooth communication in family forest owners decision making. Scand J For Res 23 (5): 466-477.

Kenny DC. 2017. Modeling of natural and social capital on farms : toward useable integration. J Ecol Model 356 (2017): 1-13.

Kurniadi R, Purnomo H, Wijayanto N, Fuah AM. 2017. The refusal of livestock owners towards exclusion policy In protected area. J Manajemen Hutan Tropika, 23 (1): 16-24. [Indonesia]

Kusumastuti A. 2015. Modal sosial dan mekanisme adaptasi masyarakat pedesaan dalam pengelolaan dan pembangunan infrastruktur. Jurnal Sosiologi Masyarakat 20 (1): 81-97. [Indonesian]

Liu J, Qu H, Huang D, Chen G, Yue X, Zhao X. 2014. The role of social capital in encouraging residents pro-environmental behaviors in community-based ecotourism. J Tour Man 41: 190-201.

Maladi Y. 2010. Eksistensi hukum adat dalam konstitusi negara pasca amandemen. Jurnal Mimbar Hukum 22 (3): 450-464. [Indonesia]

Muslimah M, Yulida R, Eri S. 2015. Analisis modal sosial dalam program pemberdayaan masyarakat di desa Sungai Pinang Kecamatan Tambang Kabupaten Kampar. Jom Faperta 2 (1).

Nandini R. 2013. Evaluasi pengelolaan hutan kemasyarakatan (HKM) pada hutan produksi dan hutan lindung di Pulau Lombok. Jurnal Penelitian Hutan Tanaman 10 (1): 43-55. [Indonesia]

Nysten-haarala S. 2013. Creating trust in institutions in Russian forest localities. J For Pol Econ 31 (2013): 12-19.

Paletto A, Ferretti F, Meo ID. 2012. The role of social networks in forest landscape planning. J For Pol Econ 15 (2012): 132-139.

Parlinah N, Nugroho B, Saleh MB. 2018. Possibility of harnessing social capital to support the development of payment for environmental services in small-scale forests: A case of Jatigede catchment area. Jurnal Manajemen Hutan Tropika 24 (2): 70-80. [Indonesia]

Purnomo H. 2003. Model dinamika sistem untuk pengembangan alternatif kebijakan pengelolaan hutan yang adil dan lestari. Jurnal Manajemen Hutan Tropika 9 (2): 45-62. [Indonesian]

Putnam RD.1993. The prosperous community. Social capital and public life. Am Prospect 13: 35-42

Putnam RD, Leonardi R, Nonetti RY. 1993. Making democracy work: civic tradition in modern Italy. Princeton University Press, Princeton, NJ.

Ramansyah F, Sayamar E, Yulida R. 2015. Analisis modal sosial anggota kelompok wanita tani dalam program model kawasan rumah pangan lestari (M-KRPL) di Desa Tualang Kecamatan Tualang Kabupaten Siak. Jom Faperta 2 (1)

Rijal M, Noer S. 2013. Peran modal sosial dalam pelestarian hutan. Jurnal Kebijakan Dan Administrasi Publik 17 (2): 20-36. [Indonesia]

Roslinda E. 2018. Social capital of the community in the management of Danau Sentarum National Park, West Kalimantan, Indonesia. Biodiversitas 19 (4): 1249-1257

Roslinda E, Ekyastuti W, Kartikawati SM. 2017. Social capital of community forest management on Nusapati village, Mempawah District, West Kalimantan, Indonesia. Biodiversitas 18 (2): 548-554.

Schluter A, Koch M. 2011. Institutional change in the forest sector : trust and mental models. Eur J Forest Res 130: 383-393.

Senoadji G. 2011. Perilaku masyarakat badui dalam mengelola hutan, lahan, dan lingkungan di Banten Selatan. Jurnal Humaniora 23 (1): 115. [Indonesian] 
Sevilla CG, Tuwu A, Syah A. 1993. Pengantar Metode Penelitian. Universitas Indonesia Press, Jakarta. [Indonesia]

Simon H. 2003. Hutan jati dan kemakmuran. Problematika dan strategi pemecahannya. Bigraf Publishing, Yogyakarta. [Indonesian]

Tulaeva S. 2013. Institutional trust: The process of trust formation in Russian forest villages in accordance with the international system of forest certification. J For Pol Econ 31: 20-27.

Uphoff N. 2000. Understanding social capital: Learning from the analysis dan experience of participation. In: Dasgupta P, Serageldin I (eds).
Social capital a multifaceted perspective. Washington DC: World Bank.

Usman S. 2018. Modal Sosial. Pustaka Pelajar, Yogyakarta. [Indonesian]

Yoder L, Roy R. 2018. Tracing social capital : how stakeholder group interactions shape agricultural water quality restoration in the Florida Everglades. J Land Use Pol 77 (2018): 354-361. 